\title{
Usage of indicators of innovativeness in marketing performance assessment in companies in Slovakia
}

\author{
Dana Hrušovská ${ }^{1, *}$ and Katarína Grančičová ${ }^{1}$ \\ ${ }^{1}$ University of Economics in Bratislava, Faculty of Business Management, Dolnozemská cesta 1, 852 \\ 35 Bratislava, Slovakia
}

\begin{abstract}
At present, measuring of marketing performance should be an integral part of a comprehensive evaluation of the performance of a company. In this context, the paper points out the trend of the increasing number of indicators used in the area of marketing performance assessment and summarizes the most commonly used indicators in this area, with an emphasis on the innovativeness indicators. Following the theoretical bases it subsequently presents the results of the research more broadly aimed at the issue of marketing performance assessment in companies in Slovakia. The presented results are focusing mainly on the usage of indicators of innovativeness, which have been in companies in Slovakia identified as the least preferred category of indicators in the context of marketing performance assessment. The overall results of the implemented research suggest that the general trends in the examined area to a large extent apply also to companies in Slovakia.
\end{abstract}

\section{Introduction}

At present, measuring and evaluating marketing performance should be an integral part of a company's marketing activities. The importance of this issue increases with the amount of resources invested in marketing and is gradually becoming a competitive factor of the company. Only with the correct assessment can a company acquire an idea if financial resources for marketing activities were used in an adequate manner and positively influenced the results and the overall performance of the company $[5,21]$. The problem is that there is no uniform and universal method for this purpose. In this regard, the paper points out the trend of the increasing number of indicators used in the area of marketing performance assessment. Based on research from foreign scientific sources it also summarizes the most commonly used basic categories and indicators of marketing performance assessment. Following these theoretical bases, it presents the results of research focused on the assessment of marketing performance in companies in Slovakia, with an emphasis on the category of innovativeness indicators.

\footnotetext{
* Corresponding author: dana.hrusovska@euba.sk
} 


\section{The theoretical bases of the examined issue}

The interest in the issue and conceptual development of marketing performance assessment can be dated back to the 1960s [9]. Numerous studies of this concept have been carried out since then, but it is still debated and is considered elusive. Thus, marketing performance has been and remains the center of marketing interest for the vast majority of organizations [10]. Therefore, both academics and practitioners are constantly looking for clear and reliable tools for assessing the merits of marketing [13].

\subsection{Basic approaches in the field of marketing performance assessment}

Overall, it can be noted that most sources summarize the developments and approaches in marketing performance assessment into two basic approaches. The traditional approach that uses mainly financial or accounting measuring tools and the approach that uses nonfinancial measuring tools - approach based on marketing audit.

In the traditional approach, measuring marketing performance has been limited to determining marketing productivity, i.e. determining the amount of output achieved through a single unit of marketing input, in order to quantify how marketing contributes to the success of the company. The analysis on the input side included the individual expenditures on marketing activities and these were compared with the outputs - sales volume, profit, $\mathrm{CF}$, i.e. mainly accounting measuring tools. Several studies were focused on finding the optimal allocation of marketing resources with the aim to maximize profitability. Pajtinková et al. [12] states that the limitations of this approach can be seen particularly in the false assumption that marketing outputs and inputs can be precisely evaluated and that, over time, they remain stable and also that productivity is primarily based on the quantity of inputs and outputs without evaluation of their quality. Marketing productivity thus underestimates the long-term value that marketing creates. Monitoring business strategies also requires measuring tools that can capture the potential from the point of view of future performance. On the other hand, it points out that this approach has also been beneficial in terms of important information that constitutes a conceptual model of marketing productivity providing a comprehensive view of the effectiveness of dimensions that enter into marketing performance and current understanding of the importance and the quantification of marketing expenses and revenues.

A significant shift in the evaluation of marketing performance occurred in the 1980s and especially in the 1990s when the need and the awareness of the importance of non-financial indicators started to get stressed. Clark $[4,11]$ stated that in this period the strongest trend in marketing performance evaluation in various sectors was a step from measuring the success of products to indicators oriented on customer value. In this context, he indicated the gradual addition of non-financial measuring tools to traditional accounting indicators market share, quality of provided services, customer satisfaction and loyalty, brand value, as well as broader considerations regarding marketing audit.

One of the aspects that caused this shift was also the gradual transition from transactional to relational marketing. While transactional marketing aims to maximize the number of one-off transactions (passive target orientation and marketing activities seen only as cost items) [16], the objective of relational marketing is to develop long-term relationships with profitable customers (focusing on quality and value of long-term customer relationships or other decisive interest groups). Customer expectations in both pre-sale and post-sale processes are a key. Gradually, there has been an increase in the interest in defining and improving the "correct" marketing inputs, with an emphasis on whether companies actually conduct proper marketing activities in a way that creates valuable assets contributing to the long-term financial performance of the company. The 
result of this gradual evolution in the field of marketing performance assessment is an approach based on marketing audit, which makes it possible to evaluate precisely the quality and efficiency of marketing inputs [12]. This approach is currently being developed in an effort to identify modern methods for optimizing the allocation of resources for marketing activities, while the issue of marketing assets is coming to the forefront $[17,18]$. At the same time, some authors suggest the usefulness of a holistic approach to marketing performance evaluation [19].

\subsection{Basic categories of indicators of marketing performance assessment}

The aforementioned development in the field of approaches is also reflected in the individual indicators used to measure marketing performance. At present, therefore, the number and diversity of tools for marketing performance assessment available to companies have increased considerably. For example, Clark [4] identified around 20 key indicators; Davidson [14] selected 10 key marketing efficiency metrics out of the hundreds of indicators identified by Mayer [15]. Farris [7] currently lists nearly 120 basic marketing indicators for the needs of marketing managers in 9 main categories.

Based on several surveys [1,2,3] carried out in business practice Ambler et al. determined 6 basic categories of marketing indicators. They are listed in Tab. 1 .

Table 1 Overview of basic categories of indicators for measuring marketing performance

\begin{tabular}{|c|c|}
\hline Category of marketing indicators & $\begin{array}{c}\text { Basic indicators in the respective } \\
\text { category }\end{array}$ \\
\hline Consumer perception/attitude & $\begin{array}{c}\text { Awareness; Perceived quality; Customer } \\
\text { satisfaction; Importance of the brand for the } \\
\text { customer; Perceived brand difference; } \\
\text { Knowledge of the brand }\end{array}$ \\
\hline Consumer behavior & $\begin{array}{c}\text { Number of new customers; Loyalty; } \\
\text { Conversion rate }\end{array}$ \\
\hline Business customer & $\begin{array}{c}\text { Customer satisfaction; Number of } \\
\text { complaints }\end{array}$ \\
\hline Competition-oriented indicators & $\begin{array}{c}\text { Relative customer satisfaction; Perception } \\
\text { of quality compared to competitors }\end{array}$ \\
\hline Innovativeness & $\begin{array}{c}\text { Number of new products; New product } \\
\text { revenues; New product margin }\end{array}$ \\
\hline Financial indicators & Revenues; Margin; Profit/profitability \\
\hline
\end{tabular}

Source: Processed according to [1,3]

The overview is primarily an expression of how practitioners approach marketing performance assessment and the grouping of marketing metrics, and also offers the opportunity to list the most commonly used indicators. Thanks to that it can be a useful indicator for managers in measuring and evaluating marketing performance.

The development in this area also poses some problems. One of them is the creation/formulation itself of suitable marketing indicators. On one hand, there are some demands on marketing indicators that arise from the general requirements of evaluating marketing performance, but on the other hand, business practice points out that many of them are often very specific for the field of marketing evaluation and require data that is difficult to access, is incomplete and complicated [6,7]. As the number of indicators for measuring marketing performance increases, there is often unnecessary tracking of too large a range of indicators. Therefore, in order for companies to avoid an information overload, it is necessary to select only those that are important to the company/marketing, i.e. they will be sufficient to effectively monitor marketing, but also its impact on the 
overall results and performance of the company [20]. The choice of indicators thus becomes as important as the performance measurement itself. Of course, in parallel to this, it is necessary to develop techniques and tools that will allow this monitoring. Finally, it should also be noted that the identification of suitable measuring indicators does not automatically improve performance, but merely enables managers to find and identify areas where there is a potential to improve performance [22].

\section{Research design}

The aforementioned theoretical foundations became the basis for formulating the objectives and research questions of the presented part of the research, which is overall aimed at identifying the current state and knowledge in the field of marketing performance assessment in companies in Slovakia. This research is to some extent following a similar research carried out in the United Kingdom, China, Spain [1, 2, 3], thus allowing a possible comparison with abroad. The presented part of the research aims to determine the state of the usage of the category of indicators of innovativeness in marketing performance assessment in companies in Slovakia. The individual research questions were formulated as follows:

RQ1: What is the extent of usage of the category of innovativeness indicators in comparison with other categories in marketing performance assessment in companies in Slovakia?

RQ2: What is the extent of usage of basic indicators in the category of innovativeness to measure marketing performance in companies in Slovakia?

RQ3: For the individual basic indicators in the category of "innovativeness" to find out: What is the importance, the frequency of tracking and the way of evaluation of a specific indicator in the examined category in companies in Slovakia?

At the same time on the basis of statistical survey, the aim was to verify which of the examined factors/characteristics of companies influence the tracking of innovativeness indicators (within the framework of marketing performance assessment) in companies in Slovakia.

In addition to general methods of scientific work, a questionnaire was used as a basic tool for data collection as part of the research task. Its first part was conceived in such a way as to enable obtaining of the basic characteristics of the respondent/company. The second part of the questionnaire dealt with areas such as need, importance, approaches, surveyed indicators, but also problems in the field of marketing performance assessment. Data collection took place between November 2016 and March 2017 in companies in Slovakia, using simple random sampling and the sampling units were companies. The sample consisted of 500 companies, of which 286 were subsequently included in the database $(57.2 \%$ return). The sample of the companies involved in the research was examined and characterized in several respects - the size of the company, the structure of the company, the affiliation and time of activity in the sector, the prevailing market orientation of the company and the importance of marketing in the company. The selection of these identifying characteristics resulted from their possible impact on the field of marketing performance assessment. The obtained data were evaluated using mathematicalstatistical methods (Chi-Square Test and Cramer's coefficient).

\section{Results and discussion}


This part is focused on presentation and interpretation of partial results obtained from the survey carried out in companies in Slovakia, with emphasis on research questions mentioned in the section - research design of this paper.

From the results of the solution of the overall research task, it can be noted that out of the total number of companies included in the survey (286), more than $2 / 3(68.8 \%)$ consider it necessary to measure and evaluate the marketing performance in the company. At the same time, most of these companies also carry out this assessment $-62.7 \%$ which can be seen as positive. Companies that do not measure marketing performance gave as the most common reasons: size of the company; lesser importance of marketing in the company; company structure - i.e. evaluations are carried out at the headquarter level and also the difficulty of this issue both in terms of data and specialists. At the same time, it can be noted that, according to the examined characteristics, marketing performance is measured and evaluated to a great extent by - large companies $(85 \%)$; companies with their own individual marketing department $(87 \%)$; companies operating in consumer markets and in the retail sector $(75 \%)$ and also companies that have been operating in the industry for a long time - i.e. according to the survey results, the longer the period of activity in the industry the higher the rate of assessment of marketing performance (more than 50 years $83 \%$, up to 1 year - $33 \%$ ).

In the $1^{\text {st }}$ research question (RQ1), the subject of the research were the basic categories of measuring instruments of marketing performance and their preference by companies in Slovakia in evaluating their marketing success. The basic categorization of marketing performance assessment tools was based on theoretical bases and it divided the indicators into 7 groups - financial indicators, competition-oriented indicators, indicators evaluating consumer perception and attitude, indicators evaluating consumer behavior, indicators focused on business customer, indicators of innovativeness. The results in the area of preference of basic categories of marketing performance assessment tools of companies in Slovakia are shown in Fig.1.
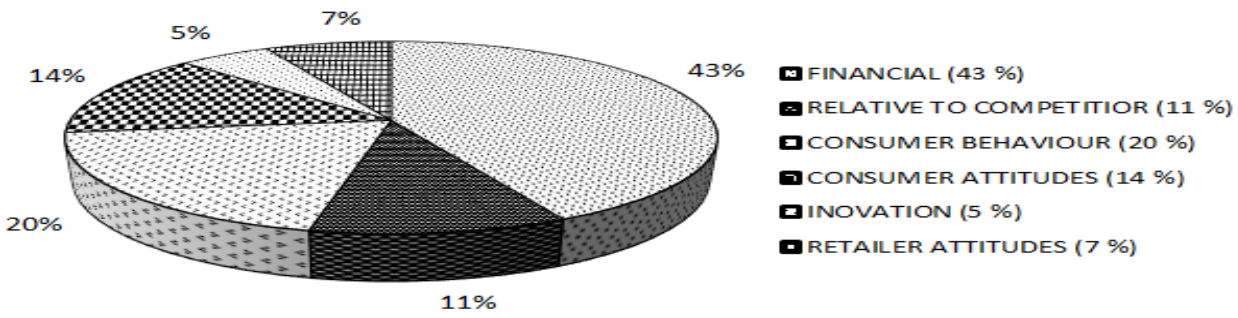

Fig.1. Preferences in terms of basic categories of marketing performance assessment indicators of companies in Slovakia Source: own research

The most preferred and also most frequently tracked category is financial indicators, which are preferred by $43 \%$ of companies that operate in Slovakia and assess marketing performance. On the other hand, the category of indicators of innovativeness, which are also the subject of further examination in this part of the research, are among the least preferred indicators $(5 \%)$ to assess marketing performance and success compared to other categories of indicators. These findings also correlate with the theoretical bases [4] and the results of the studies that inspired this research [1,2,3]. As a rule, the basic reason for favoring financial indicators is the simple acquisition of data for their evaluation and comparison, while the indicators of innovativeness are perceived as "lifeblood of marketing" [8]. The presented results can also be supplemented by a $\%$ of tracking of the individual marketing indicators for marketing performance assessment in companies in Slovakia. The first 5 most tracked indicators are listed in Table 2. 
Table 2 Extent of usage/tracking of individual marketing indicators in the field of marketing performance assessment in companies in Slovakia

\begin{tabular}{|c|c|}
\hline Indicator & \% of tracking \\
\hline Customer satisfaction & $95.74 \%$ \\
\hline Sales/Revenues & $93.12 \%$ \\
\hline Profit & $91.62 \%$ \\
\hline Perception of quality & $85.19 \%$ \\
\hline Margin & $76.60 \%$ \\
\hline
\end{tabular}

Source: own research

These results were followed by a survey within the individual categories of indicators, while in the category of indicators of innovativeness (RQ2) were identified as the most frequently measured indicators in companies in Slovakia - the number of new products, revenues from new products, the margin from new products and the customer satisfaction with new products. It can be noted that companies that track this category of indicators in general track the majority of the most basic primary metrics at approximately the same rate. Table 3 provides an overview of their usage in terms of marketing performance assessment in companies in Slovakia.

Table 3 The extent of usage of the basic indicators of innovativeness in marketing performance assessment of companies in Slovakia

\begin{tabular}{|c|c|}
\hline Indicator & \% of tracking \\
\hline Number of new products & $58.70 \%$ \\
\hline Revenue from new products & $69.60 \%$ \\
\hline Margin from new products & $68.25 \%$ \\
\hline Customer satisfaction with new products & $69.15 \%$ \\
\hline
\end{tabular}

Source: own research

At the same time, for the individual indicators of innovativeness, the following characteristics were examined: the importance that respondents/managers of the surveyed companies attribute to these indicators; the frequency of their tracking and the method of assessment (RQ3). The basic findings are given in Table 4. Overall, the extent of usage, the frequency of tracking and the way of evaluation of the tracked indicators meet the importance that the respondents give them as well as the nature of the indicators.

Table 4 Predominant assessment of tracked characteristics of individual indicators of innovativeness (\% of companies in Slovakia)

\begin{tabular}{|c|c|c|c|}
\hline Indicator & Importance & Frequency of tracking & $\begin{array}{l}\text { Method of } \\
\text { assessment } \\
\end{array}$ \\
\hline $\begin{array}{l}\text { Revenue from new } \\
\text { products }\end{array}$ & $\begin{array}{l}\text { High } \\
54.1 \%\end{array}$ & $\begin{array}{c}\text { Regularly/monthly } \\
47.4 \%\end{array}$ & $\begin{array}{c}\text { Comparison } \\
\text { plan/reality } \\
60.4 \% \\
\end{array}$ \\
\hline $\begin{array}{l}\text { Customer satisfaction } \\
\text { with new products }\end{array}$ & $\begin{array}{l}\text { High } \\
50.4 \%\end{array}$ & $\begin{array}{c}\text { Regularly/quarterly } \\
36.1 \%\end{array}$ & $\begin{array}{c}\text { Comparison over } \\
\text { time } \\
35.3 \%\end{array}$ \\
\hline $\begin{array}{l}\text { Margin from new } \\
\text { products }\end{array}$ & $\begin{array}{l}\text { High } \\
59.1 \%\end{array}$ & $\begin{array}{c}\text { Regularly/monthly } \\
47.0 \%\end{array}$ & $\begin{array}{c}\text { Comparison } \\
\text { plan/reality } \\
67.9 \%\end{array}$ \\
\hline $\begin{array}{l}\text { Number of new } \\
\text { products }\end{array}$ & $\begin{array}{c}\text { Rather high } \\
48.7 \%\end{array}$ & $\begin{array}{c}\text { Regularly/yearly } \\
41.0 \%\end{array}$ & $\begin{array}{c}\text { Comparison } \\
\text { plan/reality } \\
43.6 \% \\
\end{array}$ \\
\hline
\end{tabular}

Source: own research 
Finally, this survey was followed by a statistical survey of the impact of factors/examined characteristics of companies on tracking of the individual indicators of innovativeness in companies in Slovakia. With the help of the chi-square test, the assumptions about the existence of a statistically significant correlation between the marketing performance assessment of a company through the corresponding indicator and the individual examined attributes/characteristics of the company. In the case of confirmation of dependence, the Cramer's coefficient (Cramer's V) was used to measure its intensity. All tests were realized at a significance level of $p>0.05$. The results are presented for the margin from new products indicator. Only in the case of this indicator and only for one variable - the size of the company, the statistical dependence was confirmed, while its strength is moderate (Table 5). In case of the other examined indicators, the statistical dependence was not confirmed.

Table 5 Overview of the results of the chi-square test and Cramer's coefficient values for the examined variables and the margin from new products indicator

\begin{tabular}{|c|c|c|c|c|}
\hline \multicolumn{5}{|c|}{ The margin of new products } \\
\hline factor/variable & $\begin{array}{c}\text { Value Chi- } \\
\text { Square }\end{array}$ & Df & $\begin{array}{c}\text { Asymp.sig. } \\
(2 \text { sided)/p }\end{array}$ & $\begin{array}{c}\text { Cramer's } \\
\text { V Value }\end{array}$ \\
\hline company size & $\mathbf{1 2 . 9 6}$ & 5 & 0.024 & $\mathbf{0 . 2 6}$ \\
\hline company structure & 1.79 & 3 & 0.617 & 0.10 \\
\hline $\begin{array}{c}\text { business focus } \\
\text { market orientation of the } \\
\text { company }\end{array}$ & 9.17 & 5 & 0.103 & 0.22 \\
\hline $\begin{array}{c}\text { period of activity in the } \\
\text { sector }\end{array}$ & 3.48 & 1 & 0.176 & 0.10 \\
\hline
\end{tabular}

Source: own research

Overall (not only on the basis of statistical findings, but also on the basis of qualitative assessment and assessment in other categories of marketing indicators as well) it can be stated that the size of the companies is a factor that has some influence on the tracking of the individual indicators for the marketing performance assessment of companies in Slovakia. That means as it would be expected that large companies rather than smaller companies evaluate majority of the indicators.

\section{Conclusions}

The results of the survey show that most companies in Slovakia are not only aware of the importance of measuring and evaluating marketing performance, but are also dealing with it. As assumed, this applies mainly to: large companies; companies that are oriented on the consumer market; companies that have been operating on the market for a long time, have a separate marketing department and place great emphasis on marketing. It was also confirmed that they mainly use the category of financial indicators for this purpose, while from among the individual basic marketing indicators they most often use mainly the indicators: customer satisfaction, revenues, profit, quality perception and margin.

On the other hand, the innovativeness indicators examined in this paper represent the least preferred and used category for measuring and evaluating marketing performance in the surveyed companies. However, the fact that, if they already track this indicator they do so on a regular basis and in a manner corresponding to their nature can be viewed positively. The statistical verification of dependence did not confirm, however, that the tracking of the innovativeness indicators (as opposed to the indicators in other categories) depends on the characteristics of the surveyed companies. The only exception was the 
margin from new products indicator, which showed a slight connection to the size of the company.

Overall, the results of the survey confirm that the general trends of marketing performance assessment are also to a significant extent relevant for companies in Slovakia. In many areas, as well as in the area of indicators of innovativeness, they also correspond with the results of the realized researches we use as bases.

In conclusion, the creation, improvement and selection of appropriate marketing indicators in an effort to create a functional model for effective monitoring of marketing performance are a constant challenge for both marketing theory and practice. The way to solve these issues can be found in research, which also involves conducting surveys in business practice.

This paper is the outcome of the VEGA project no. 1/0646/20: "Diffusion and consequences of green innovations on imperfect competition markets" with a $100 \%$ proportion.

\section{References}

1. T. Ambler, D. Riley., Marketing Metrics: A Review of Performance Measures in Use in the UK and Spain. London Business School, London, working paper, 1-30 (2000)

2. T. Ambler, W. Xiucun, Measures of Marketing Success: A Comparison between China and the United Kingdom. Asian Pacific Journal of Management 20, 267 - 281 (2003)

3. T. Ambler, F. Kokkinaki, S. Puntoni, Assessing Marketing Performance: Reasons for Metrics Selection, Journal of Marketing Management 20, 475-498 (2004)

4. B. H. Clark, Marketing Performance Measures: History and Interrelationships, Journal of Marketing research 15, 64-73 (1999)

5. D. O'Sullivan, A. V. Abela, M. Hutchinson, Marketing performance measurement and firm performance. European Journal of Marketing 43, 843-862 (2009)

6. P. W. Farris, et al., 50+ Metrics Every Executive Should Master. (EDP Pearson Education, Inc., Upper Saddle River, New Jersey, 2006)

7. P. W. Farris, N.T. Bendle, P. Pfeifer, D. J. Reibstein, Marketing metrics: The Managers Guide to measuring Marketing Performance. (EDP Pearson Education, Inc., Upper Saddle River, New Jersey, $3^{\text {rd }}$ edition., 2016)

8. K. Simmonds, Marketing as Inovation - The 8th Paradigm. Journal of Management studies 23, 479-500 (1986)

9. R. A. Feder, How to Measure Marketing Performance. Harvard Business Review 43, $132-142(1965)$

10. N.A. Morgan, B.H. Clark, R. Gooner, Marketing Productivity, Marketing Audits and Systems for Marketing Performance Assessment. Integrating Multiple Perspectives. Journal of Business Research 55, 363 - 375 (2002)

11. B. H. Clark, A Summary of Thinking on Measuring the Value of Marketing. Journal of Targeting, Measurement and Analysis for Marketing 99, 357 -369 (2001)

12. G. Pajtinková-Bartáková, K. Gubíniová, L. Cibák, Teoretické a praktické aspekty hodnotenia marketingovej výkonnosti. Marketing Science and Inspirations 8, (2013)

13. M. Pont, R. Shaw. Measuring marketing performance: A criticque of empirical literature. ANZMAC, Conference Proceedings Adelaide 1-3 December 2003, 2064 2073 (2003)

14. J.H. Davidson, Transforming the Value of Company Reports through Marketing Measurement. Journal of Marketing Management 15, 757-777 (1999) 
15. M.W. Meyer, Finding Performance: The New Discipline in Management. Performance Measurement - Theory and Practice. (EDT Center for Business Performance, Cambrige, England, 1998)

16. L. Lamberti, G. Noci, Marketing Strategy and Marketing Performance Measurement System: exploring the relationship. European Management Journal 28, 139-152 (2010)

17. R. K. Srivastava, T.A. Shervani, L. Fahey, Market-Based Assets and Shareholder Value: a framework for analysis. Journal of Marketing 62, 2-18 (1998)

18. R. K. Srivastava, L. Fahey, H.K. Christensen, The resource-Based View and Marketing: The role of Market-Based Assets in Gaining Competitive Advantage. Journal of Management 27, 777-802 (2001)

19. N. A. Morgan, B. H. Clark, R. Gooner, Marketing productivity, marketing audits, and systems for marketing performance assessment - Integrating multiple perspectives. Journal of Business Research 55, 363-375 (2002)

20. B. H. Clark, A.V. Abel, T. Ambler, An Information Processing Model of Marketing Performance Measurement, Journal of Marketing Theory and Practice 14, 191-208 (2006)

21. D. O'Sullivan, A.V. Abela, Marketing performance measurement ability and firm performance. Journal of Marketing 71, 79-93 (2007)

22. M. Oreský, Hodnotenie efektívnosti marketingu - východiská tvorby a uplatnenia merných ukazovatelov v marketingu. Zborník vedeckých statí Obchodnej fakulty 2011, Vydavatel'stvo EKONÓM, Bratislava, 1-13 (2011) 